\title{
Protected areas in Spain ${ }^{1}$
}

\author{
M. Pa Pilar González YancI
}

\section{INTRODUCTION}

Among the wide range of scientific meetings, seminars, conferences and congresses that are held under the common denominator of Geography, it is not very usual to encounter the issue of nature protection. It is therefore very satisfying to see that the UGI had paid special attention to this issue at its 1994 Regional Conference, because geography, or rather, geographers, ought to take an active part in the fight to conserve our natural heritage, which is being spoilt at a rate that, in the recent past, nobody could have imagined. This is leading us towards a very bleak future, in which the loss, in terms of standards of living, could be irreversible.

In this brief paper, I shall attempt to describe the Spanish situation, which, for various reasons, is, without a doubt, of particular interest as regards Europe as a whole. One of the reasons I will mention first is the enormous wealth and variety of nature in this small country. Spain has often been compared to a miniature continent in which one can find the most varied coastlines, high mountains, volcanic landscapes, arid deserts, or great swamps. Moreover, the scarce population and the country's delayed development have meant that the general state of conservation of our rich natural heritage has been far better than in most European countries, which either began industrial development much earlier, or have suffered serious environmental damage due to the lack of a suitable legislation.

Este artículo corresponde a la comunicación presentada al Congreso sobre «Environtment and Quality of Life in CentraL Europe: Problems of transition", organizado por la U.G.I. y celebrado en Praga en agosto de 1994. 
I think it is therefore very important to stress, whenever we can, the need to fight for the preservation of our environment, to increase protection and protected areas, to improve the legislation and to both report and try to avoid the problems that arise as new threats every day. Some of these problems are, at times, connected to a desire for conservation that has misfired and worked against the initial aim.

\section{PROTECTED AREAS FOR NATURE CONSERVATION}

Throughout history, we have seen examples of mankind's attempts to preserve or keep certain areas, such as the one mentioned by José Cándido de Melo, at the end of the 16th century, to preserve the forest of The Hague unchanged. Yet it was not until the 19th century that part of society started to feel concerned that, in the future, some areas that could be considered of great natural value might be lost or become seriously deteriorated. Although there were some notable precedents (such as protecting the thermal spas in Arkansas, USA, in 1832, the attempt to establish a law to preserve the forest at Fontainebleau in France in 1858, or the creation of a public park belonging to the California Federal government in the Yosemite valley, in 1865), it is the year 1872 that is considered as the beginning of natural conservation policy. In that year, Yellowstone National Park was created in Wyoming, USA, although it was not until 1887 that the park was officially received this name.

The main motive at first was purely altruistic. This can be seen in the words of one of the first explorers of the region, who said: «l think that God created this area for everyone to see and enjoy. We have to prevent people from thinking they can own any of this land as their property and for their own exclusive use. This forest does not belong to any of us; it belongs to America. Let us turn it into a great park and preserve it that way. It must never be changed and let us force ourselves to keep it the way we see it now, so that all Americans throughout the ages can see how beautiful, splendid and wonderful our America was."

From the very first, the Yellowstone law aroused controversy, while at the same time the area became known worldwide. From the start, there were both those in favour of conservation and those who thought it meant restricting the development and use of all natural resources. A hundred years have elapsed since then: very great changes have taken place in our society and the risk to and deterioration of the environment has increased enormously. 
The existence nowadays of over four thousand national parks and protected regions would clearly seem to indicate that the international community wishes to give certain areas some hereditary value. However, there are many different positions on all the aspects involved in protection, and it is not unusual for the controversy on some of these issues to come to the public's attention. Over the years, some changes have been made regarding such positions, policies and the management of protected areas.

The national park idea is currently under revision. It is the most prominent idea, and the one with the clearest features and requirements. It is the most widespread throughout the world, and that which has accumulated the greatest amount of experience and has stirred up most interest. For many years it was made to be somewhat defensive, and barriers were placed between what was protected and everything else, whereas nowadays it is believed that protecting an isolated and limited area, such as an ecological island, becomes useless after a time if such protection is not included within a wider context of organizing the use of the ground and all the natural resources within a country's territory and the whole biosphere.

\section{THE CASE OF SPAIN}

Spain was one of the first European countries to unite in establishing and legislating protected areas, preceded only by Sueden, Russia and Switzerland. In 1916, a brief General Law on National Parks was proclaimed, and this was the beginning of nature conservation policy. Two years later, the first two Spanish National Parks were created: Covadonga, in the Picos de Europa range, and Ordesa in the Pyrenees.

This law was not used again until 1954, when two more parks were created, this time in the Canary Islands: Teide and the Caldera de Taburiente, and some time later Aigües Tortes and lago de San Mauricio in the Pyrenees. In 1957, a new Law, the Mountain Law (Ley de Montes), replaced the previous one, including its main points and adding clauses on expropriations and fines for offenses committed in Parks. At the same time, three new parks were created: Doñana in the Guadalquivir swamps, Las Tablas de Daimiel on the Manchegan plateau, and Timanfaya on the volcanic island of Lanzarote. 


\subsection{The 1975 Law}

At this point, there was an great spread of the idea of conservation that led to a new specific law being created and passed: the Law on Natural protected areas, which came into force in 1975 and ruled the declaration and management of such areas from then on until 1989.

The 1975 law did not come to into being without some problems. While it was being created, it was the object of much mutilation and modification so that, by many people, it was judged insufficient and unsuited to the reality of both nature and Spanish society (Rodriguez, F. 1983). The introduction to the law begins with the very expressive words: "Within general nature conservation policy...". So the law was actually created using a general nature conservation criterion, which specifed various degrees of protection but in fact it only led to the creation of small islands of protection within the areas it covered.

The law was, however, important. It established the selective protection of areas that deserved it, as well as considering such protected areas as representative elements for geography, natural heritage and the Administration. This differed with the way that, in the past, the emphasis had been placed only on forestry, shooting, or fishing areas. The law also decreed the reclassification of protected areas under four new categories:

1. Areas of scientific interest. Natural areas with a small surface area, legally declared due to their exceptional scientific value for protecting, conserving and improving their entire contents (including flora and fauna). They may be botanical, geological, or zoological, and are entirely for scientific and research purposes.

2. National Parks. Natural areas with a fairly large surface area, legally declared because of the existence within them of primitive ecosystems which have not been substantially altered by human occupation and where vegetable and animal species and geomorphological formations are of cultural, recreational, or educational interest and beauty.

These first two categories are the most strictly protected of the four.

3. Natural places of national interest. Natural areas, places or elements covering a small area, legally declared because of their specific and unique values for attending to the conservation of their flora, fauna, geomorphological elements, great beauty or any other outstanding natural element. The enjoyment and benefit of these areas must be compatible with 
the conservation of their contents. Protection is also strict, but allows the traditional use of the ground.

4. Natural Parks. Areas with natural values that are declared such in order to enable mankind to stay in touch with nature. The enjoyment of and benefit from these areas are subject to restrictions to guarantee conservation. These may be considered as mixed areas, both protected and used.

The previously existing categories (National Parks, Natural Places of National Interest, National Monuments and Picturesque Sites), had to be adapted to the above new ones, and this was done very slowly. Also, another new park was created, the ninth in Spain, called Garajonay, on the island of la Gomera in the Canary Islands. At the same time, a major task began, which consisted of making an inventory of the main natural areas in Spain. This would later serve as a catalogue for selecting areas to be protected, and taking steps to prevent the threat of deterioration. The Inventory of Specially Protected Natural Areas contained 633 areas over $7.3 \%$ of the national territory - and it is a valuable document that the Administration should use in order to establish its special protection policy.

\subsection{The current legislation and the importance of planning}

In 1989, a new law was passed on the Conservation of Natural Areas and Wild Flora and Fauna, which replaced the previous law and is currently in force in Spain. The most important point of this law is that it has established a new legal framework and has focussed especially on one aspect that had practically been forgotten under the previous law. This was the planning of natural areas, an aspect that had been called for by specialists and which merely takes into account the principle that was established by the Declaration of the United National Conference on the Environment, in Stockholm, in 1972. This Declaration stated: «Rational planning is an essential element for reconciling the differences that may arise between the demand for development and the need to protect and improve the environment."

The planning of protected areas is extremely important nowadays and a fairly controversial issue. It should be an integral part of the general planning of the use of the physical medium; precisely the part which is of most restricted use. It must also apply to all protected natural spaces as an entire system. It must have overall objectives and, in 
particular, it must provide each area with a series of guidelines and rules for its management.

As it may well be said that, as a rule, there is no well-defined and accepted idea of how the planning of protected natural areas should be carried out, any attempts made in this direction are likely to arouse controversy.

In Spain, action is taken on two levels: the State and the Autonomous Communities. The latter, in several cases, have full authority on issues regarding the protection of natural areas, and also have their own legislation. For example, there is the 1985 Law on Natural Areas, in Catalonia, which was replaced by the Areas of National Interest Scheme of 1992 , or the statutory law 6/1987 on Regional Urbanistic Rules for the Protection and use of Navarrese territory, which defines four categories for the protection of natural areas of interest in the Autonomous Community of Navarre. In the same way, some Communities, such as Asturias and Valencia, are writing up their own Organizational Scheme for Natural Resources, and the Governing Scheme for the Use and Management of Natural Areas, respectively. The State itself has retained the authority to act in situations of interest to the nation or which affect several Communities at the same time; more specifically, it deals with National Parks, which are of supraregional interest, and it both declares and manages such areas.

Nowadays, when the national Government expresses a desire to declare new national parks, the protection issue has been at the forefront, at times even stepping into the news. It is a complex situation. Under the 1989 law, currently in force, the planning of protected areas is carried out according to various elements: the Natural Resources Organization Scheme (PORN), which must be drawn up and approved prior to the declaration of a national park or a protected area, and the Governing Scheme for Use and Management (PRUG), which establishes the rules governing a park and regulates any activities that may take place there. Also, for national parks there are what are known as "special schemes", which are approved by administrative bodies at a lower level than the Government, and which regulate specific aspects (such as visits, traditional use, etc). There are also Integral Development Schemes and Promotion Programmes. All these are known as "environmental planning tools."

The legal framework for planning natural areas is therefore established but, as the 1989 law is not statutory, many questions and problems arise in practice when the management schemes for most protected natural areas are not in fact approved, as in such important national parks as Ordesa or Covadonga. 


\subsection{Problems}

When an attempt is made to put legal requirements into practice, it can be seen that many issues have still not been defined. If we analyze the situation of the 17 Autonomous Communities on issues involving protected areas, it becomes apparent that there are a considerable number of problems.

In Spain at present there are some 500 protected areas, making up 5\% of the national territory, although the figures provided by various sources do not coincide, due to the lack of connection among various administrations. The first essential problem is the non-existence of a general scheme, as only national parks are nationally administered. The Autonomous Communities, which in themselves are very heterogeneous, in every sense, have various differing policies. Some have a lot of protected areas, such as the Canary Islands, in which $42 \%$ of the land is classified, and which have four national parks, or the Rioja, which has none at all. However, most Communities are either studying or drawing up both the declaration of new areas and their own legislation on these issues. Some are even in open conflict with the Government due to their refusal accept the declaration of national parks within them (for example, there is Cantabria, which is against the Picos de Europa park).

But the problems do not end here. There are many other different ones. In general, very few resources are provided for maintenence, so that protection is at times merely theoretical. Some Communities want to extend their protected areas from $4 \%$ to $20 \%$ (Catalonia) without increasing the budgets of the administrative Departments in charge of them.

Another delicate problem is the response of local inhabitants and those affected by the declaration of areas of interest. This is very important in some cases, and legal action has been taken (for example the inhabitants of Cornalvo, in Extremadura, won a case against their land being declared a natural park and are currently awaiting the Supreme Court's final decision). In general, farmers are opsed to these declarations, and they clash with ecologists or anything they consider related to them, such as the declaration of parks. They are afraid of their land being expropriated, or else they complain that their freedom is restricted and that they feel that living in a protected area will be detrimental to them. At times there are complaints because once an area has been declared to be of interest, heavy tourism is attracted to it. The inhabitants want to "exploit" this new situation and discover that, precisely because it is a protected area, there are restrictions and difficulties involved. The declaration of protected areas does not, in fact, take into account sufficiently the needs of the inhabitants, who are 
offered no alternatives or interesting projects compatible with the new situation and which would enable them to live there.

In general, there is no awareness among the population of the importance of protected natural areas. For most people, it is just a "tourist" issue, part of a new fashion. It is nice to visit "pretty places", but the main point is not considered, and even, at times, regarded with some mistrust. The declaration of protected areas also generates tremendous touristic activity, which, in turn, brings problems. The fact that an area is classified as protected, attracts a large number of people who, more often than not, have a negative impact on the environment (an increasing problem, for example, is the use of four-by-four vehicles merely for enjoyment). The most wellknown areas, or those which are close to big cities, are most affected by this (Ordesa, one of the first Spanish national parks, and La Pedriza, a natural park of enourmous interest, close to Madrid, are examples).

From the above, it may be deduced that the protection of natural areas is an extremely important issue, but one that means a great deal of attention must be payed to the problems that arise around it. The case of Spain is of great interest, due to the country's wealth of nature, but it is in serious danger. Proposals have been made by ecologist groups (for example, CODA, the Coordinator of Environmental Defence Organizations, which contains 170 ecological groups), to increase the number of national parks to 32, and even to declare international parks between Spain and France, or Spain and Portugal. For this purpose, they propose that a large budget should be provided and that management should be carried out that would enable quiet and controlled rural tourism to develop, and that would promote farming and fishing resources.

My proposal runs along the same lines. A major task must be performed. A protection policy for natural areas must be established (for all of them, and of course, in particular those of special interest). It must be a general policy (not merely within each State). At the same time, sufficient means must be provided for its correct management, and the inhabitants of these areas must be taken into account. Instead of giving them additional problems, it should be made easier for them to live in harmony with the environment, and in adequate conditions. Tourism may be developed, but must be tightly controlled (avoiding too much pressure on certain areas, establishing and enforcing suitable restrictions and prohibitions, etc.), and, of course, the population should be provided with environmental education, without which it is impossible ot preserve the wonderful natural surroundings that we have inherited and which we are bound to leave as a legacy to future generations. 


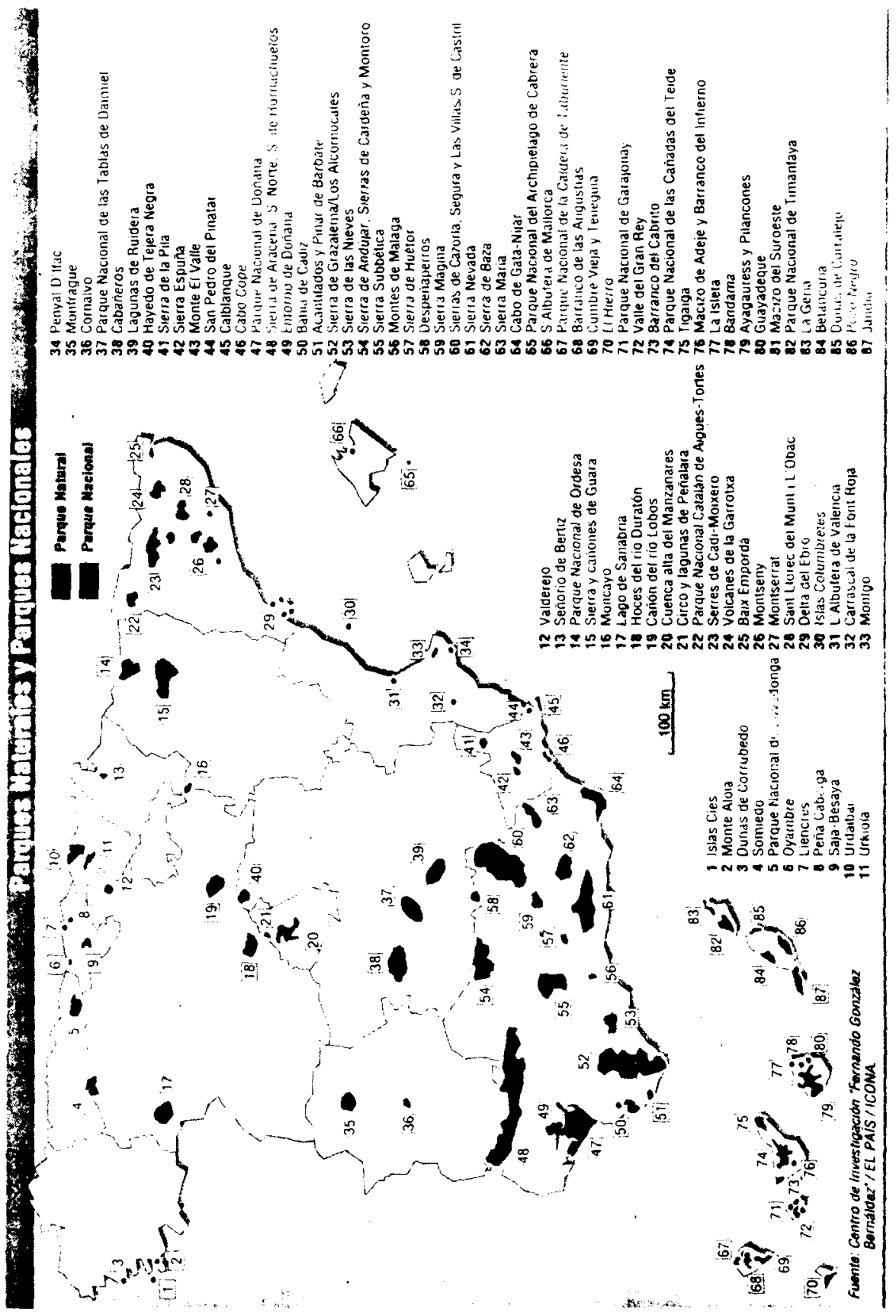




\section{BIBLIOGRAPHY}

Banco BILBAo-VIzCAYA (1993): "Espacios naturales protegidos". Rev. El Campo, $n^{0} 128,246$ pp.

Blas ARITIO, L. (1981): Guía de los Parques Nacionales Españoles. Incafo. Madrid, $142 \mathrm{pp}$.

Castroviejo, M. (1991): Prácticas para la Planificación de espacios naturales. Colección Técnica. ICONA. Madrid, 358 pp.

Davis, G. E.; Halvorson, W. L.; Ehorn, W. H. (1988): "Science and Management in National Parks». Bull. Ecol. Soc. Amer., 69 (2) pp.111114.

DeLIBES, M. (1985): “Los espacios protegidos no garantizan la conservación de la Naturaleza». Rev. Quercus, 21, pp. 6-9.

PALUzIE, L. (1990): Los espacios naturales Protegibles. Su Protección, regulación legal e incidencia en la ordenación del territorio. Universitat Politécnica de Catalunya. Barcelona. $231 \mathrm{pp}$.

MARiN, C. (1991): “Planificación del suelo y de espacios protegidos». En Práctica para la Planificación de espacios naturales. ICONA. Madrid. pp. 41-48.

Rodriguez MARTín, F. (1993): «Uso y gestión en las áreas naturales protegidas españolas". En Seminario de especialistas sobre formación para manejo de áreas protegidas. Centro Internacional de Formación en Ciencias Ambientales. Caracas.

VIedma, M. G., et AlLII (1982): Planificación y gestión de espacios naturales Protegidos. Fundación Conde del Valle de Salazar. Madrid, 423 pp. 